\title{
In vitro inhibition of mumps virus by retinoids
}

\author{
Kaitlin J Soye ${ }^{1,2}$, Claire Trottier ${ }^{1,2}$, Thomas Z Di Lenardo ${ }^{1,2}$, Katherine H Restori ${ }^{1,2}$, Lee Reichman ${ }^{1}$, \\ Wilson $\mathrm{H}$ Miller $\mathrm{Jr}^{2}$ and Brian J Ward ${ }^{1,3^{*}}$
}

\begin{abstract}
Background: Mumps virus (MuV) is a highly infectious paramyxovirus closely related to measles virus (MeV). Despite the availability of a mumps vaccine, outbreaks continue to occur and no treatment options are available. Vitamin A and other naturally occurring retinoids inhibit the replication of MeV in vitro.

Methods: Anti-viral effects of retinoids were observed in cell culture using the myelomonocytic U937, NB4/R4, and Huh7/7.5 cells. Observations of anti-viral effect were quantified using TCID50 analysis. Molecular properties of the antiviral effect were analysed using quantitative RT-PCR and western blot.

Results: The current work demonstrates that retinoids inhibit MuV in vitro due to up-regulation of type I interferon (IFN) and IFN stimulated genes. This effect is mediated by nuclear retinoid receptor signalling and RIG-I is required. The antiviral retinoid-induced state makes cells less permissive to viral replication from subsequent challenge with either MuV or MeV for less than 12 hours.

Conclusions: These results demonstrate that retinoids inhibit MuV replication in uninfected bystander cells through a retinoid inducible gene I (RIG-I), retinoic acid receptor (RAR) and IFN dependent manner making them refractory to subsequent rounds of viral replication. These observations raise the possibility that pharmacological doses of retinoids might have clinical benefit in MuV infection.
\end{abstract}

\section{Text}

The Paramyxoviridae are single stranded, enveloped, negative sense RNA viruses. They are among the most important viral pathogens of humans and animals. Many of the Paramyxoviridae replicate only in the respiratory epithelium, but Morbillivirus and Rubulavirus members typically have wider tissue tropism and can cause severe, systemic disease [1]. Paramyxovirdae epidemics in virgin populations can be devastating [1]. Vaccines are available for only a small number of the Paramyxoviridae and antiviral drugs are not yet available for most of these agents.

Mumps virus $(\mathrm{MuV})$ is a Rubulavirus in the Paramyxoviridae family. It is the causative agent of mumps [2]. $\mathrm{MuV}$ is a highly contagious infection of humans and was historically one of the most common childhood illnesses. The virus infects and replicates in the nasal mucosa and upper-respiratory tract [2]. A transient cell-associated

\footnotetext{
* Correspondence: brian.ward@mcgill.ca

${ }^{1}$ Research Institute of the McGill University Health Center, Department of Infectious Diseases, McGill University, Montreal, Quebec, Canada

${ }^{3}$ Montreal General Hospital, 1650 Cedar Ave., Room L10-309, Montreal, Quebec H3G 1A4, Canada

Full list of author information is available at the end of the article
}

viremia (of mononuclear cells) contributes to systemic viral spread [2]. In young children, $\mathrm{MuV}$ infection is typically a mild disease characterized by fever, headache and swelling of the salivary glands. Complications such as meningitis, encephalitis or orchitis may occur. Mumps is a leading cause of acquired sensorineural deafness among children. Rates of post-infectious meningoencephalitis can be 1-10\% of clinical mumps cases. Although the fatality rate of mumps encephalitis is low (0.1-0.5\% of clinical mumps cases), the risk of permanent neurologic sequelae in encephalitis cases is $25 \%$ [3]. Furthermore, MuV infection during the first trimester of pregnancy is associated with a $25 \%$ incidence of spontaneous abortion [3].

There is no current treatment for mumps other than supportive care [2]. Vaccination programs in developed countries have markedly increased the average age at which clinical mumps occurs and dramatically reduced the incidence of mumps infection [2]. Unfortunately, large outbreaks have recently occurred in Europe, North America, Australia and Israel [4-12].

In the last 2 decades, many studies have documented the beneficial effects of vitamin A supplements on general mortality and/or morbidity in young children in a wide

\section{Biomed Central}

(c) 2013 Soye et al.; licensee BioMed Central Ltd. This is an open access article distributed under the terms of the Creative Commons Attribution License (http://creativecommons.org/licenses/by/2.0), which permits unrestricted use, distribution, and reproduction in any medium, provided the original work is properly cited. 
range of developing countries. In 2000, a meta-analysis of eight studies demonstrated an overall $30 \%$ reduction in infant mortality attributable to vitamin A supplements [13-15]. A surprising spin-off from these vitamin A supplementation studies was the re-discovery that vitamin A 'treatment' can significantly decrease the morbidity and mortality associated with acute $\mathrm{MeV}$ infection [16-19]. The mechanism underlying the positive effects of vitamin A supplements and treatment in measles are not well understood [13]. Since the mid-1990s, the WHO and UNICEF have recommended vitamin A treatment for acute measles in regions of the developing world with high mortality rates [20].

Vitamin A (retinol) is a fat-soluble vitamin. Its natural and synthetic derivatives as well as metabolites are collectively referred to as retinoids [21,22]. Retinol is obtained from the diet as either retinyl esters or carotenoids. Retinoids are required for a wide-range of crucial biological processes including regulation of embryonic development, maintenance of the integrity of epithelial cell surfaces, vision and immunity [23]. The metabolite, all-trans retinoic acid (ATRA) is responsible for mediating many of the important biological functions of retinoids [22]. ATRA is the natural ligand for retinoic acid receptors (RAR), which form heterodimers with the retinoid X receptors (RXR) within the nucleus [24]. RAR-RXR heterodimers bind to retinoic acid response elements (RARE) on the promoters of target genes to activate transcription when bound by ligand $[21,22,24]$. The protein products of retinoid-responsive genes are responsible for exerting the effects of retinoids in the cell.

Retinoids have been shown to play a role in innate immune responses and to regulate the expression of a number of interferon stimulated genes [25-27]. Of particular interest among the retinoid-responsive genes is the type I interferon (IFN) pathway. A powerful trigger for type I IFN production is the recognition of virus-associated molecular patterns by pattern recognition receptors [28]. These cytokines trigger a rapid and strong innate defense against many viruses, leading to the transcription of several hundred ISGs controlled by the IFN-stimulated gene factor 3 (ISGF3) complex [29].

Of particular importance to the current work, retinoids have specifically been implicated in regulating expression of the ISG (Interferon Stimulated Gene) retinoid-inducible gene I (RIG-I) and IFN regulatory factor 1 (IRF-1) [30-39]. RIG-I is a pattern recognition receptor that was originally understood to detect 5'-triphosphorylated, single-stranded RNA [40-42] and is expressed at a basal level in many cell types. The current consensus is that the minimal requirement for RIG-I activation is a blunt-ended base paired RNA 10-20 bp long with a 5 triphosphate [43]. It can initiate the production of type I IFN and is itself an ISG [44]. IFN has been reported to induce RIG-I expression by causing the IRF-1 transcription factor to bind to the RIG-I promoter [45].
Anti-MeV effects of retinoids have been observed in a number of primary human cells and cell lines of diverse tissue origin [46-48], including the myelomonocytic U937 cells, which were an important model for our work with $\mathrm{MuV}$ presented herein. We hypothesize that ATRA treatment during other viral infections would also have an antiviral effect. We set out to test whether or not $\mathrm{MuV}$ replication could be inhibited by retinoids. Based on our previous studies, we hypothesize that retinoids would inhibit $\mathrm{MuV}$ replication in vitro and that this inhibition would depend upon RAR signalling, type I interferon and functional RIG-I.

\section{Results}

\section{Mumps virus can be inhibited in vitro}

U937 cells are neoplastic and histiocytic progenitors of monocytes that have been extensively used in immunological studies [49] including investigation of interferon pathways during $\mathrm{MuV}$ infection [50-52]. In these cells, increasing doses of retinol resulted in a significant inhibition of $\mathrm{MuV}$ replication as quantified by $\mathrm{TCID}_{50}$ (Figure 1A). Significant inhibition was achieved at concentrations as low as $1 \mu \mathrm{M}$, a dose at which increased expression of the retinoid responsive gene RAR $\beta$ is readily observed (Figure 1C) [53]. Treatment of U937 cells with increasing doses of ATRA was even more effective as an inhibitor of MuV output (Figure 1B) and in the induction of RAR $\beta$ mRNA expression (Figure 1D) [53]. All subsequent investigations of the antiviral effect of retinoids on $\mathrm{MuV}$ were performed using ATRA at a dose of $1 \mu \mathrm{M}$.

\section{Retinoid treatment enhances IFN signalling}

The innate immune response is thought to be responsible for the initial control of infectious agents. It has long been known that up-regulation of the type I IFN response functions in an auto-response feedback loop that is critically important for antiviral responses. In the U937 model, MuV infection alone is able to induce the expression of IFNa1 mRNA (Figure 2A). However, ATRA treatment of MuV infected cells synergistically increases the expression of IFN $1 \mathrm{mRNA}$ and supernatant protein levels (Figure 2A-B). IFN $\beta$ mRNA expression and protein levels are also synergistically increased by the combined treatment of ATRA and MuV infection (Figure 2C-D).

The increased type I IFN production leads to the expression of ISGs. In the U937 model, IRF-1 mRNA expression is significantly increased over control by ATRA treatment alone (Figure 2E), in agreement with our previous work [47] and the literature [30,38,39]. However, treatment of $\mathrm{MuV}$ infected cells with ATRA further increases the expression of IRF-1 mRNA (Figure 2E). This combined treatment (MuV + ATRA) resulted in a robust increase in RIG-I mRNA expression (Figure 2F). The mRNA levels of two other IFN-responsive 
A

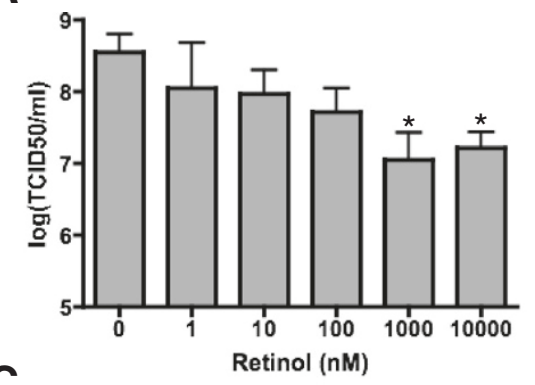

C

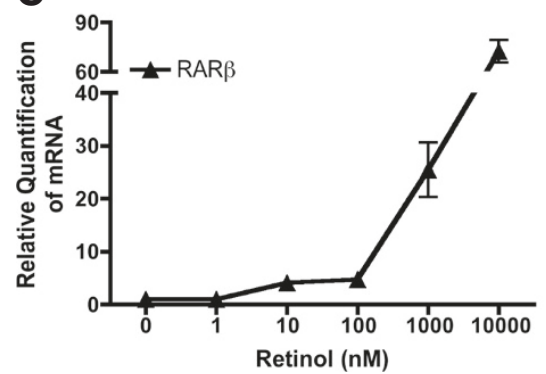

B
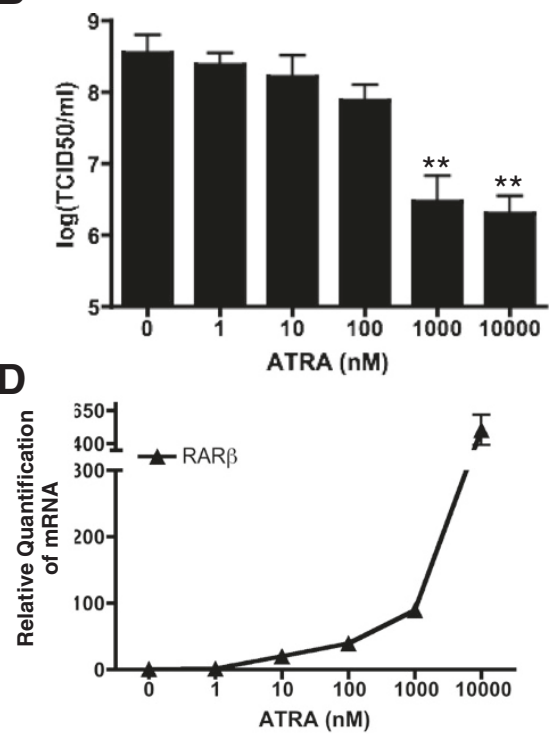

Figure 1 In vitro inhibition of mumps virus by retinoids. (A) (B) U937 cells were infected with MuV at an MOI of 0.01 and treated with increasing doses of retinol or all-trans retinoic acid (ATRA) as indicated. Whole cell lysates were harvested after 48 hours and viral titers were measured by TCID 50 . (C) (D) RNA was extracted from parallel U937 cultures treated with increasing doses of retinol or ATRA and analyzed for RAR- $\beta$ expression by qPCR. Data presented reflect three experiments performed in triplicate $(N=3)$. ${ }^{*} p<0.05$, ${ }^{* *} p<0.01$.

genes, IRF-7 and MDA-5, also showed similar patterns of increased expression in response to MuV + ATRA (data not shown). In addition to the regulation of ISG expression, treatment of MuV infected U937 cells with ATRA also increased STAT1 activation as indicated by phosphorylation of tyrosine 701 (Figure 2G).

The increased expression of these ISGs can be attributed to the increased activation of the type I IFN pathway. When a monoclonal antibody specific to IFN $\alpha / \beta$ receptor 1 was used to prevent IFN signalling during $\mathrm{MuV}+\mathrm{ATRA}$ treatment, ISG mRNA expression was blocked, as demonstrated by RIG-I mRNA (Figure 2H). This observation demonstrates that IFN signalling is required for the retinoid-MuV antiviral response.

\section{Functional nuclear retinoid receptors mediate antiviral activity of retinoids}

To determine whether the antiviral activity of retinoids requires nuclear receptor signalling, we utilized the well-characterized NB4/R4 cell model (retinoid responsive versus retinoid unresponsive) [54]. NB4 cells respond to ATRA at pharmacologic concentrations, while the NB4 subclone R4 is completely resistant, regardless of the concentration $[54,55]$. Both NB4 and R4 cells were readily infected with MuV. In NB4 cells, $1 \mu \mathrm{M}$ of ATRA was able to inhibit $\mathrm{MuV}$ output but had no effect in R4 cells (Figure 3A). At this concentration, the level of inhibition observed was unlikely due to retinoid-driven differentiation of the NB4 cells $[46,48]$. Like the U937 cells, expression of the ISG, IRF-1, was also increased in NB4 cells exposed to ATRA alone but was higher in cells exposed to $\mathrm{MuV}+\mathrm{ATRA}$ infection (Figure 3B). IRF-1 mRNA expression was very low during $\mathrm{MuV}$ infection alone in this model. In the retinoid-unresponsive R4 cells, IRF-1 expression was not seen either with ATRA treatment alone or in response to $\mathrm{MuV}+\mathrm{ATRA}$ (Figure 3B). Exogenous IFN $\beta$ treatment alone was not able to induce the expression of IRF-1 in either cell line, suggesting the requirement of ATRA for IRF-1 expression.

RIG-I mRNA expression was also significantly increased by the combined treatment of MuV + ATRA in NB4 cells (Figure 3C). Both $\mathrm{MuV}$ alone and ATRA alone increased the expression of RIG-I over mock treatment, but the expression was greatly enhanced by combined treatment. Neither ATRA, nor MuV + ATRA induced the expression of RIG-I mRNA in R4 cells (Figure 3C). When treated with exogenous IFN $\beta$, both NB4 and R4 cells increased the expression of RIG-I mRNA suggesting that IFN signalling is functional in both cell lines (Figure 3C). Expression of other ISGs, including IRF-7 and MDA-5, showed a similar pattern of up-regulation in NB4 cells and no response in R4 cells (data not shown).

As a further confirmation of the role of RAR $\alpha$ mediated signalling in the retinoid-MuV antiviral response, treatment of U937 cells with RO 41-5253, a specific RAR $\alpha$ antagonist, reversed the impact of ATRA on MuV replication and reduced the expression of the ISGs in response to $\mathrm{MuV}+\mathrm{ATRA}$ (data not shown). 


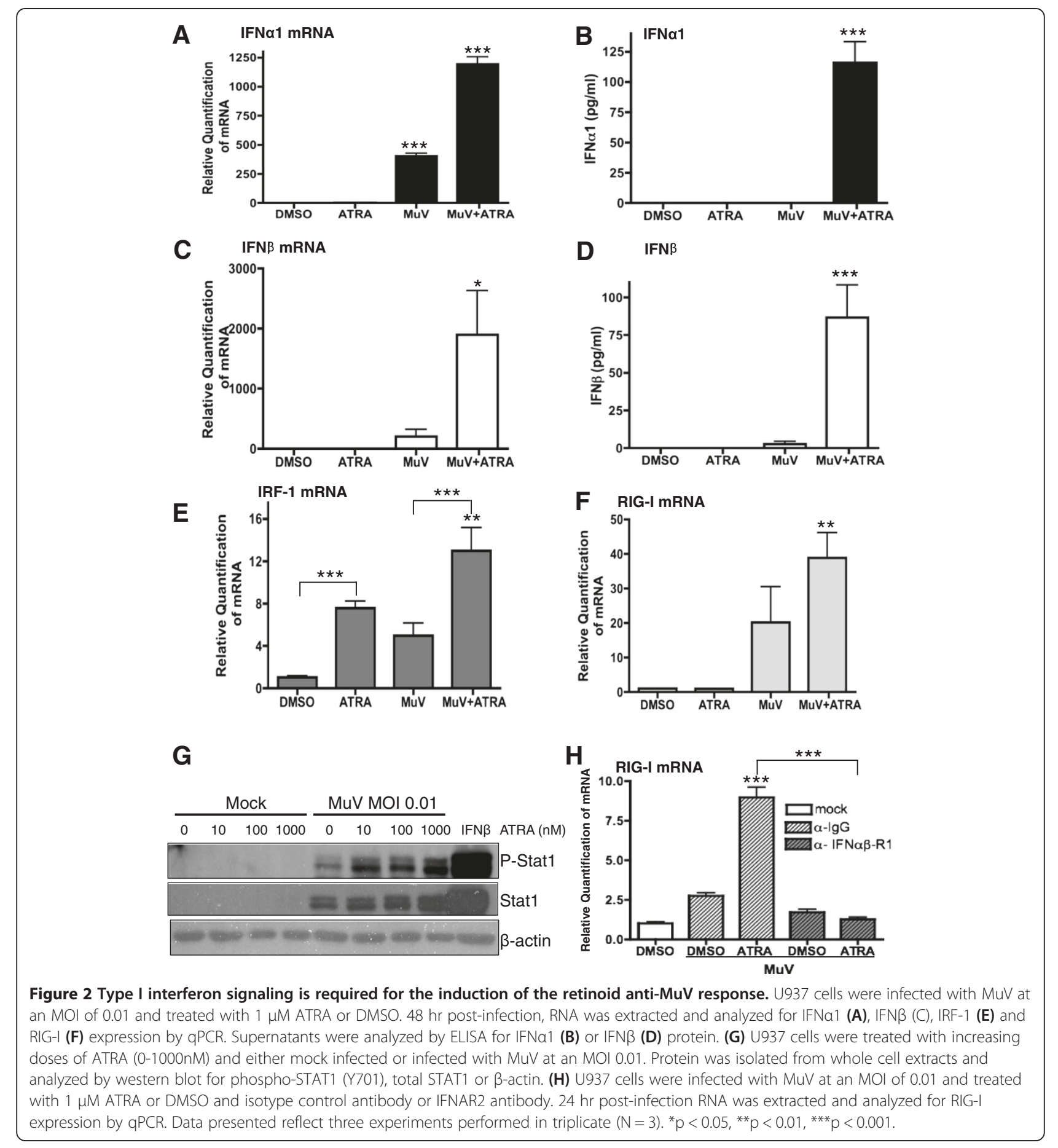

\section{RIG-I is required for the retinoid-induced antiviral response}

RIG-I is both retinoid responsive and IFN stimulated. It was clearly up regulated in our in vitro model systems in response to $\mathrm{MuV}+$ ATRA (Figures 2F, 3C). To investigate the requirement of RIG-I signalling in the cellular response to combined MuV + ATRA exposure, we used the Huh7 cell line, which is derived from a human hepatocellular carcinoma and has been used extensively in hepatitis $\mathrm{C}$ virus $(\mathrm{HCV})$ research $[56,57]$. Of particular interest for our studies, an Huh7 subclone (Huh7.5) has a point mutation in the first CARD domain of RIG-I, rendering the protein non-functional [57,58].

We turned to the Huh7/7.5 model to demonstrate the importance of RIG-I rather than using RNA interference (RNAi) after initial experiments demonstrated that both 


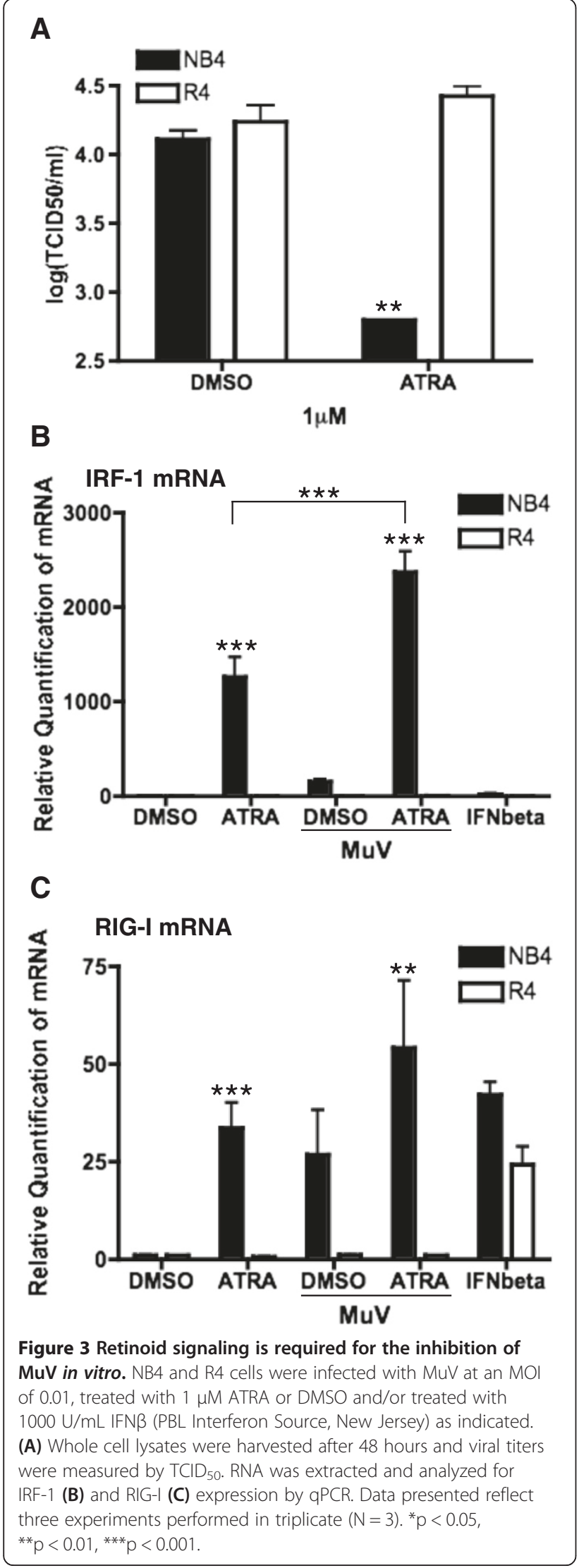

control and RIG-I specific siRNA were sufficient to induce the expression of RIG-I and other interferon stimulated genes (data not shown, also demonstrated in $[59,60])$. In MuV infected Huh7 cells treated with ATRA, virus output was significantly reduced (Figure 4A) but ATRA had no effect on MuV replication in the Huh7.5, RIG-I non-functional cells (Figure 4A).

It has recently been demonstrated that RIG-I complementation in Huh7.5 cells can restore the IRF3 pathway, making these cells less permissive to Sendai virus $(\mathrm{SeV})$ infection [58]. This observation suggests that the non-functional RIG-I encoded in the Huh7.5 cells can be complemented by exogenous expression of the protein. When RIG-I was transfected into the Huh7.5 cells, inhibition of $\mathrm{MuV}$ replication was restored (Figure 4B). These data demonstrate the requirement of RIG-I in the retinoid-MuV antiviral response.

Antiviral response is created in uninfected bystander cells To determine whether or not a bystander effect was induced following $\mathrm{MuV}$ infection, we repeated key experiments using $0.02 \mu \mathrm{m}$-pore membrane transwell tissue culture inserts (depicted in [48] and [47]). In these experiments, the inner-chamber U937 cells could be exposed to the products of infection in the outer-chamber cells without direct contact with either $\mathrm{MuV}$ itself or the MuV-infected cells. We confirmed that MuV was not able to cross the membrane by $\mathrm{TCID}_{50}$ assay of the inner-chamber cells in each experiment.

ATRA-stimulated ISG expression was just as strong in the inner-chamber (uninfected) as the outer-chamber (infected) cells despite the absence of active infection. Specifically, we found strong up-regulation of mRNA expression for IRF-1 (Figure 5A) and RIG-I (Figure 5B), as well as MDA-5 and IRF-7 (data not shown), in the inner-chamber cells.

When the supernatant (or conditioned media) from the inner-chamber bystander U937 cells was applied to fresh cells, we observed a striking induction in the expression of these same ISGs as shown for RIG-I (Figure 5C).

\section{Bystander cells are protected from infection}

To determine whether or not the uninfected inner-chamber, bystander cells would have reduced susceptibility to future infection these cells were harvested and challenged with $\mathrm{MuV}$ at an MOI of 0.1 immediately following incubation in the transwell. Compared with control cells not treated with ATRA and exposed to the products of $\mathrm{MuV}$ infection, the inner-chamber cells were relatively resistant to $\mathrm{MuV}$ replication (one log reduction in $\mathrm{MuV}$ titres produced, Figure 6A). This relatively refractory state persisted for up to 6 hours but was lost at 12 hours (Figure 6B). 

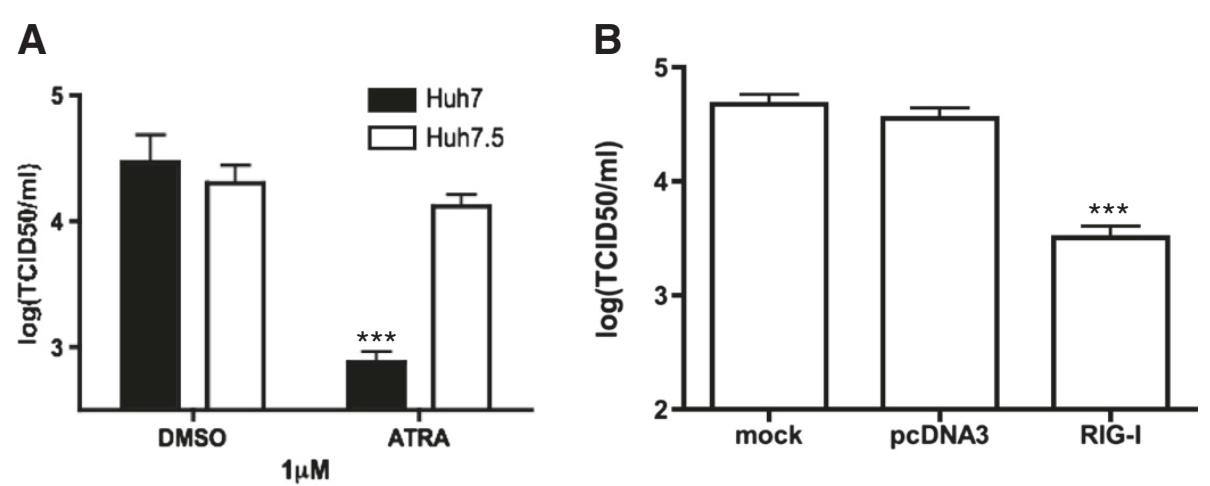

Figure 4 RIG-I is required for the inhibition of MuV by retinoids. (A) Huh7 and Huh7.5 cells were infected with MuV at an MOI of 0.01 and treated with $1 \mu \mathrm{M}$ ATRA or DMSO. Whole cell lysates were harvested after 48 hours and viral titers were measured by TCID 50 . (B) Huh7.5 cells were transfected with mock, pcDNA3.1 or pRIG-I-myc and incubated overnight. Following transfection, the cells were infected with MuV at an $\mathrm{MOI}$ of 0.01 and treated with $1 \mu \mathrm{M}$ ATRA. Whole cell lysates were harvested after 48 hours and viral titers were measured by TCID $D_{50}$. Western blotting was not performed since Huh7.5 cells produce a defective RIG-I protein that cannot be distinguished from the wild-type protein by commercially-available antibodies. Data presented reflect two experiments performed in triplicate $(N=2){ }^{* * *} p<0.001$.

These data suggest that the antiviral state created in the bystander U937 cells is short lived.

When inner-chamber bystander cells treated with ATRA and exposed to the products of $\mathrm{MuV}$ infection were challenged with $\mathrm{MeV}$ at an $\mathrm{MOI} 0.1 \mathrm{MeV}$ replication was also reduced by at least 1 log compared to untreated controls or cells treated with only ATRA or exposed to the products of outer-chamber $\mathrm{MuV}$ infection (Figure $6 \mathrm{C}$ ). The antiviral state induced in these cells was not virus-specific.

\section{Discussion}

The potential role of individual micronutrients in specific infectious diseases has been the subject of considerable interest for decades (reviewed in [61]). To our knowledge, retinol (Vitamin A) is currently the only micronutrient routinely used to 'treat' a viral disease. In fact, both vitamin A supplementation and therapy appear to have significant clinical benefit in natural $\mathrm{MeV}$ infection [16-19,21]. However, the effects of vitamin A on viral infections have been highly variable and at times, completely contradictory.

Although reduced mortality from diarrheal disease is associated with vitamin A supplements in children of the developing world this benefit appears to be due largely to milder bacterial infections $[14,62,63]$. In Mexican children receiving vitamin A supplements, the incidence of Norovirus diarrhea was reduced but gut viral titres and the period of virus shedding in these children were both significantly increased [64].

In human immunodeficiency virus (HIV) infection, pre-antiretroviral treatment (ART) studies suggested that low serum retinol levels were associated with rapid progression of acquired immunodeficiency syndrome (AIDS) but later studies showed little-to-no impact of supplements on disease progression or survival (reviewed in [65]). Perinatal vitamin A supplements in HIV-positive women can improve the survival of the seronegative children but can increase mother-to-child HIV transmission [65], possibly through increased viral loads in breast milk [66]. In vitro, retinoids have been found to both increase and decrease HIV replication in different model systems $[67,68]$.

Patients infected with Hepatitis $\mathrm{C}$ virus $(\mathrm{HCV})$ and treated with 9-cis retinoic acid or ATRA in combination with pegylated IFN $\alpha$ have lower viral loads $[69,70]$. In contrast, supplements do not increase viral clearance in human papilloma virus (HPV)-infected women [71].

Both vitamin A supplementation and treatment have either no or negative effects on respiratory tract infections including the common paramyxovirus, respiratory syncytial virus (RSV) [72-74]. Studies with another paramyxovirus have shown that vitamin A deficient chickens suffer increased morbidity from Newcastle disease virus (NDV) [75-77]. Using the paramyxovirus most closely related to measles, our group has demonstrated that canine distemper virus (CDV)-infected ferrets treated with vitamin A develop less severe disease [78]. In aggregate, these observations suggest that vitamin $\mathrm{A}$ and its derivatives may play an important role in antiviral responses but demonstrate clearly that mechanistic studies are essential to fully understand and exploit this potential.

Previously we have shown that retinoids can inhibit $\mathrm{MeV}$ replication in vitro via retinoid nuclear receptor activating type I IFN signalling $[46,48]$. We hypothesized that ATRA treatment during $\mathrm{MuV}$ infection may also inhibit $\mathrm{MuV}$ replication in vitro. We further sought to determine if the retinoid-MuV antiviral response would require type IFN signalling, RAR signalling and functional RIG-I. The current work demonstrates that ATRA similarly exerts anti-viral effects on $\mathrm{MuV}$. We believe that 


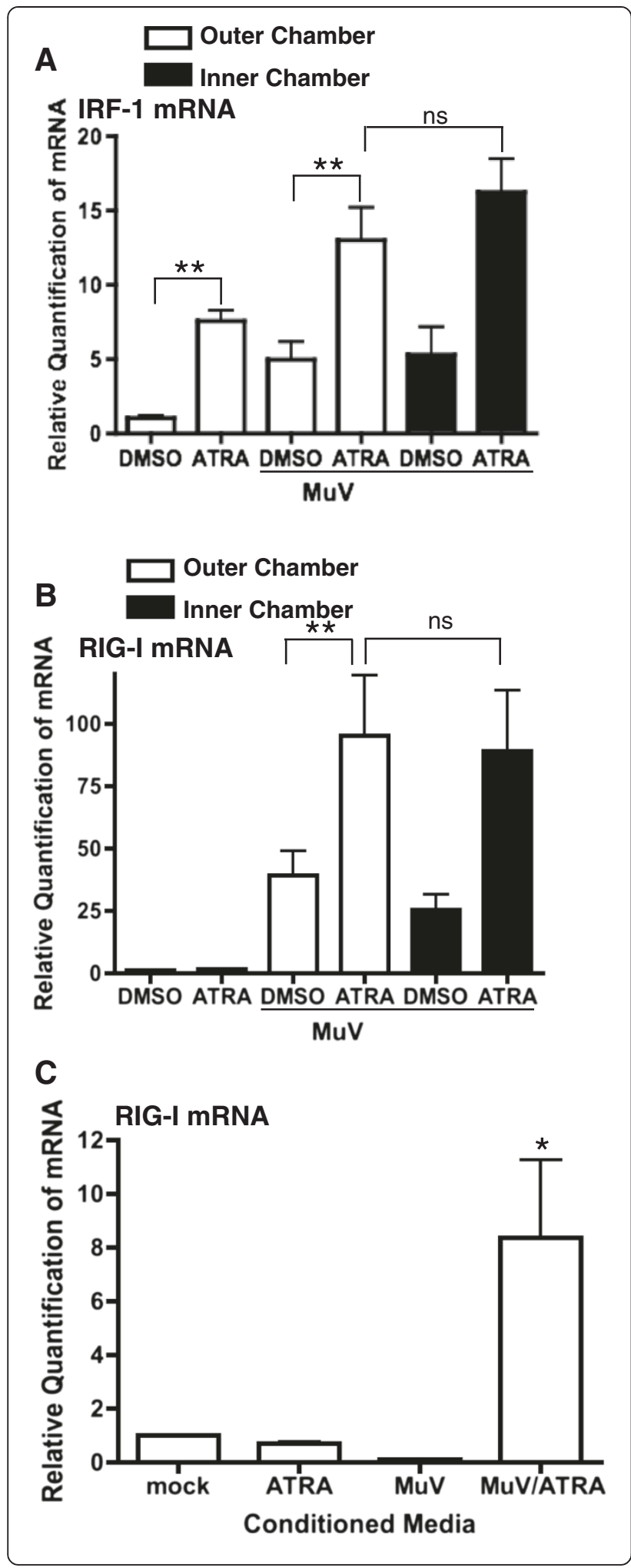

Figure 5 Retinoids induce an anti-MuV state in the uninfected, bystander cells. U937 cells were infected with MuV at an MOI of 0.01 in the presence of $1 \mu \mathrm{M}$ ATRA or DMSO. Transwell membrane inserts with $0.02 \mu \mathrm{m}$ pores were used to separate the infected cells in the outer chamber from the uninfected, bystander cells in the inner chamber [48]. Cells from control wells (no membrane insert), outer and inner chamber bystander cells were harvested after 48 hours and IRF-1 (A) and RIG-I (B) mRNA were measured by GPCR. As indicated on the Figure, outer chamber cells infected by MuV are represented by open bars and inner chamber (uninfected) cells are represented by the filled bars. (C) Conditioned media from the control and transwell inner chambers were applied to fresh U937 cells. After 24 hours of incubation with the conditioned media, RNA was extracted and RIG-I expression was analyzed. Data presented reflect three experiments performed in triplicate $(N=3) .{ }^{*} p<.02,{ }^{* *} p<0.01$.

these effects are not virus-specific, but rather extend to multiple members of the Paramyxovirus family or more broadly, to viruses that are detected by RIG-I. Figure 7 depicts our current understanding of retinoid action on Paramyxovirus infection. In Figure 7A, ATRA alone has no protective capacity on initially infected cells. These cells will produce the same amount of virus as untreated cells and ultimately, will die as a result of infection. However, the initially uninfected cells in the culture are primed for ISG expression by ATRA treatment through activation of the nuclear retinoid receptors. In Figure 7B, retinoid-primed cells effectively up-regulate ISG expression and type I IFN production upon viral infection. The combination of type I IFN and ATRA induces RIG-I expression in uninfected bystander cells, further improving the innate anti-viral response. ATRA is essential for initiating positive feedback through RIG-I activation and type I IFN pathways, which protects uninfected cells.

In the current work, we used a variety of in vitro models to extend our central observation of retinoid-induced antiviral effects to $\mathrm{MuV}$ (Figures 1A, 1C, 3A, 4A). Although the cell lines used in this work varied in their overall sensitivity to retinoids (NB4 > U937 > Huh7>> R4), all supported the growth of $\mathrm{MuV}$. Retinoid-induced suppression of $\mathrm{MuV}$ replication could be demonstrated in all but the $\mathrm{R} 4$ cells. Retinol ( $\mathrm{ROH})$ is the form of vitamin A found in the circulation at concentrations up to $2 \mu \mathrm{M}$ [79]. The degree of inhibition of MuV replication was much greater using ATRA, a natural derivative of $\mathrm{ROH}$ and ligand that binds directly to nuclear receptors. ATRA is generally found in the intracellular space, but can be found in the serum in the 5-10 $\mathrm{nM}$ range [79]. As a result, we believe the mechanisms that we have documented in vitro to be potentially active in vivo. Indeed, the outcome of any infection is essentially a 'race' between pathogen replication and the developing immune response. In this context, it is plausible that the modest reduction in the rate of $\mathrm{MuV}$ replication that we observed with retinoid 'treatment' 

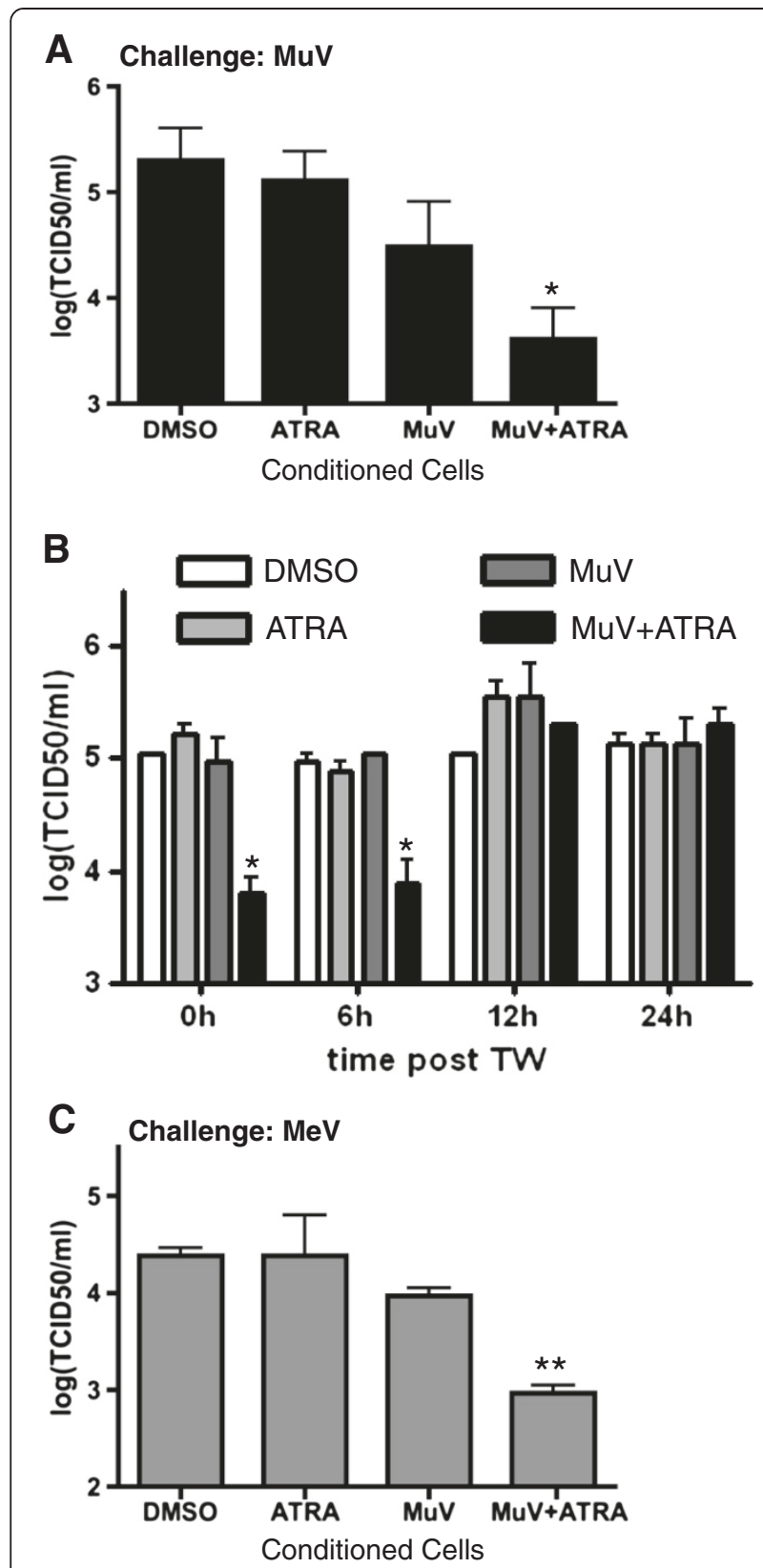

Figure 6 Antiviral state is short-lived and virus non-specific. (A) The inner chamber bystander cells were harvested and challenged with MuV at an MOI of 0.1. Whole cell lysates were harvested after 48 hours and viral titers were measured by TCID 50 . (B) To assess the duration of the anti-viral state, U937 cells were suspended in TW inner-chamber conditioned media and incubated for the indicated time at $37^{\circ} \mathrm{C}$ then challenged with $\mathrm{MuV}$ at an $\mathrm{MOl}$ of 0.1 . Whole cell lysates were harvested after 48 hours and viral titers were measured by $\mathrm{TCI}_{50}$. (C) The inner chamber bystander cells were harvested and challenged with $\mathrm{MuV}$ at an $\mathrm{MOI}$ of 0.1 . Whole cell lysates were harvested after 48 hours and viral titers were measured by TCID ${ }_{50}$. Data presented are representative of two-three experiments performed in triplicate $(N=2-3) .{ }^{*} p<0.05,{ }^{* *} p<0.01$. in vitro could translate into clinical benefit during natural disease, as occurs with vitamin A treatment in natural $\mathrm{MeV}$ infection. To our knowledge, there has not yet been any attempt to use retinol (or other retinoids) to modulate the course of mumps infection. Unfortunately, there is no animal model for mumps in which this possibility can be directly tested.

The antiviral state created by the combination of $\mathrm{MuV}$ infection and ATRA treatment was ultimately generated by the expression of type I interferon. We have demonstrated that the combination of MuV + ATRA leads to transcription of IFN genes and at least additive increases in IFN $\alpha 1$ and IFN $\beta$ levels in culture supernatants, as well as enhanced transcription of ISGs (Figure 2A-F). Increasing doses of ATRA in the context of MuV infection led to marked increases in STAT1 activation (Figure 2G) and, when type I IFN signalling was blocked, the antiviral state is lost (Figure $2 \mathrm{H}$ ). MuV normally escapes type I IFN control by targeting STAT1 for proteasomal degradation. Variations in the $\mathrm{V}$ protein sequence can decrease the efficiency of proteosomal targeting of STAT1, [80] resulting in differing sensitivity to type I IFNs and potentially the IFN dependent antiviral state produced by retinoid treatment. We are currently collecting wild-type $\mathrm{MuV}$ isolates to correlate retinoid sensitivity with $\mathrm{V}$ protein sequence to better understand this apparent paradox. At the current time, we also cannot fully explain differences in ATRA-induced up-regulation of RIG-I expression between the U937 and NB4 cells other that to postulate greater retinoid sensitivity in the RIG-I promoter of the former line. It is also possible that the timing of sample collection contributed to these results. Similarly, the timing of sampling may underlie the up-regulation of RIG-I mRNA in NB4 cells in response to IFN $\beta$ stimulation despite the apparent absence of IRF-1 induction (Figure 3B/C). Time course studies are currently underway to address these issues.

We further demonstrate that nuclear retinoid receptor signalling was also central to the antiviral effect of retinoids against $\mathrm{MuV}$. Although it is possible that more than one nuclear receptor may be involved, our current data suggest that RAR $\alpha$ plays an important role in mediating the antiviral effects against MuV. In our NB4/R4 model, RAR signalling was not only required for the antiviral effect (Figure 3A), it was essential for the expression of ISGs that contribute to the antiviral response (Figure 3B-C).

Finally, we demonstrate a similar retinoid signalling mechanism in response to MuV + ATRA (Figures 2E, 3C, Figure 4A). Most convincing, we have shown that overexpression of RIG-I in Huh7.5 cells with non-functional RIG-I signalling, can reinstate the retinoid-induced inhibition of MuV. The results in the Huh7.0/7.5 model are particularly interesting because $\mathrm{MuV}$ output does not differ greatly at 48 hours, suggesting that intact RIG-I 


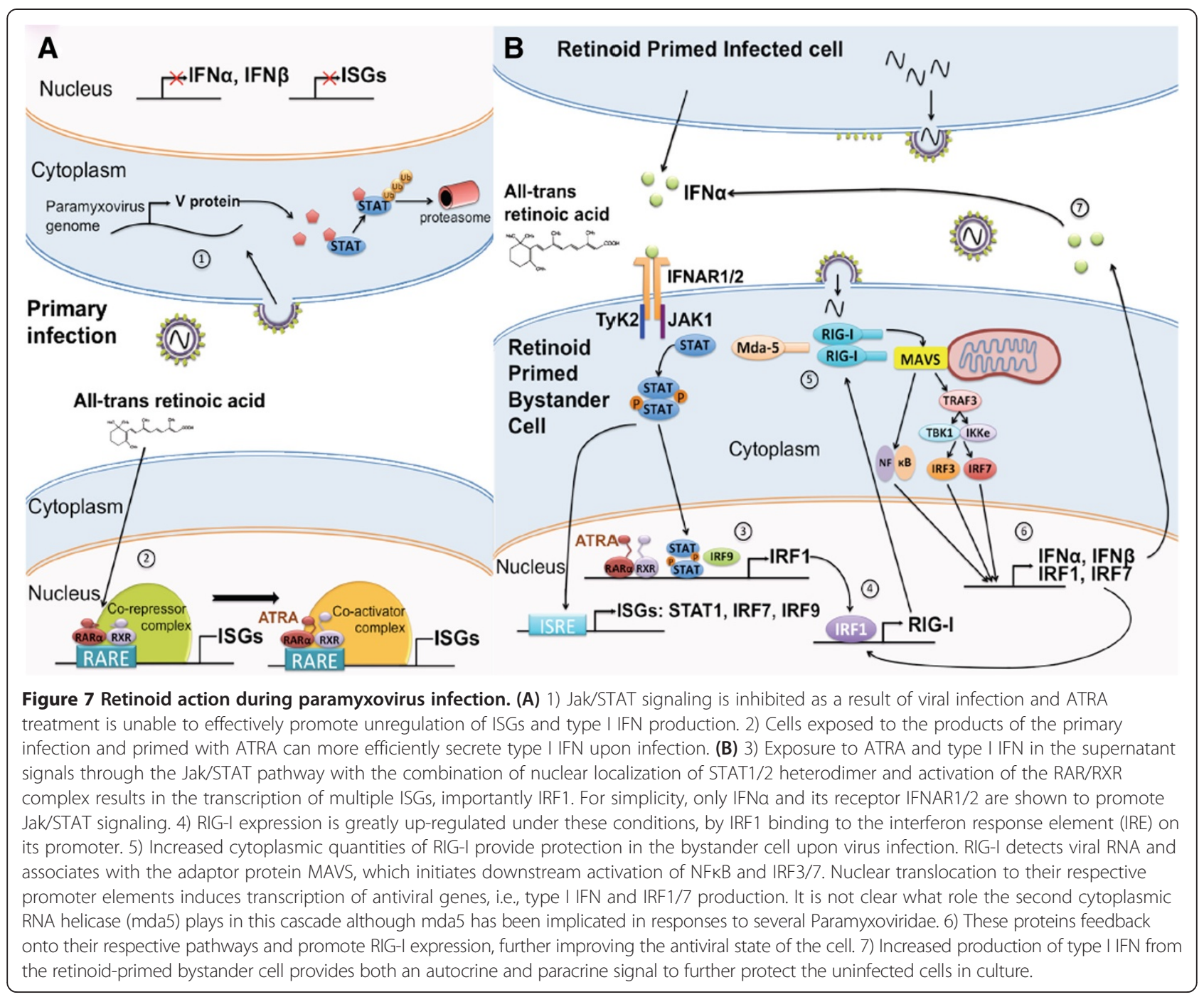

signalling (by itself) does not play a major role in limiting viral replication. However. transfection of a functional RIG-I clearly restores retinoid responsiveness in this model. At least some of this paradox may be explained by the 48-hour time-point used for most experiments. Indeed, $\mathrm{MuV}$ output was lower in the Huh7.0 than Huh7.5 cells for the first 24-36 hours (data not shown). The 48 hour time-point was chosen for our experiments because retinoid effects were most obvious at this time. These findings are very similar to our observations with measles virus in the Huh 7.0/7.5 model where transfection of a dominant negative RIG-I eliminates the anti-viral activity of retinoids in the Huh 7.0 cells and transfection of a functional RIG-I gene into Huh 7.5 cells restores activity [47].

The Huh7.0/7.5 data are also intriguing because they suggest a larger role for RIG-I in defending against $\mathrm{MuV}$ than would have been predicted from the literature to date. It is widely thought that the double-stranded RNA sensor mda- 5 is the primary target of the $\mathrm{MuV} V$ protein
$[81,82]$ and that RIG-I may respond primarily to Paramyxovirus defective interfering particles [83]. For several Paramyxoviruses, mda-5 signalling is inhibited by direct binding of the $\mathrm{V}$ protein and conserved residues in the helicase [82]. More recent data raises the possibility that Paramyxovirus $\mathrm{V}$ proteins may also target RIG-I indirectly by binding to laboratory of genetics and physiology 2 (LGP2) [84] Mutations in the carboxy-terminal domain of the $\mathrm{V}$ protein can result in a reduction or total loss of this interference [81]. In both NB4 and U937 cells, mda- 5 expression is also increased by ATRA alone (data not shown). We are currently collecting wild-type (WT) MuV isolates to assess their susceptibility to retinoid-induced suppression and to correlate this suppression with $\mathrm{V}$ protein mutations. Our preliminary data (4 low-passage isolates to date) suggest that sensitivity to retinoid-induced suppression varies widely in WT MuV (50\% suppressible) It is also interesting that retinoid sensitivity has been maintained in the two initially sensitive 
WT isolates despite repeated in vitro passage in Vero cells in our laboratory.

The antiviral state created by $\mathrm{MuV}+$ ATRA was most profound in the initially uninfected bystander cells (Figure 5A-B) and could be transferred to fresh cells via the conditioned media leading to up-regulation of ISG expression (Figure 5C). Not surprisingly, since type I IFN responses are innate and non-specific, cells exposed to conditioned media from $\mathrm{MuV}+$ ATRA cells were relatively resistant to subsequent challenge with either $\mathrm{MuV}$ or $\mathrm{MeV}$ for less than 12 hours (Figure 6A-C). This last observation is consistent with the immediate and short-lived antiviral effects of type I IFNs [85].

The Paramyxoviridae including $\mathrm{MeV}, \mathrm{MuV}, \mathrm{RSV}, \mathrm{CDV}$, phocine distemper virus, Nipah virus and Hendra virus are among the most important human and animal pathogens. Commercial vaccines are not yet available for many of these viruses, and antiviral drugs are typically of little use [86]. Some of these viruses can have extraordinarily high mortality rates (for example, CDV in naïve seals and dogs, Nipah and Hendra viruses in man) [87]. The clinical evidence of benefit from retinoid therapy of $\mathrm{MeV}$ infection in children and CDV infection in ferrets is strong [17-19,78]. Our in vitro data suggest that ATRA may be far more potent that retinol in mediating antiviral effects. Our mechanistic studies in different tissue culture models of $\mathrm{MuV}$ infection suggest that common signalling pathways mediate these effects [46-48]. However, high doses of vitamin A in children with RSV infection have no benefit and may even cause harm $[74,88]$. In aggregate, these clinical and laboratory observations support further studies of the efficacy and mechanism of action of retinoids against a wider range of respiratory viruses in more sophisticated animal models, such as primates, or even clinical studies. It would be of particular interest to use retinoids other than retinol, ATRA in particular, in these latter studies to achieve more effective inhibition of viral replication. This conclusion is further supported by a recent study demonstrating that several synthetic retinoid analogues have much greater capacity to interfere with human herpes virus 8 (HHV8) replication in vitro than retinol [89].

\section{Conclusions}

In conclusion, this work has demonstrated that $\mathrm{MuV}$ can be inhibited in vitro by retinoids. This antiviral effect required RAR signalling, type I IFN signalling and functional RIG-I. The antiviral response was created in the initially uninfected bystander cells and was both short-lived and cross-protective against subsequent $\mathrm{MuV}$ or $\mathrm{MeV}$ challenge. This is the first work to demonstrate the antiviral effect of vitamin A on $\mathrm{MuV}$ and may contribute to better treatment options for MuV. We propose that IRF-1 is recruited to the RIG-I promoter under the influence of ATRA alone, and is required for the induction of RIG-I (47). In these models systems therefore, ATRA inhibits MuV replication through the RAR $\alpha$-dependent regulation of RIG-I and IRF-1 and via an IFN feedback loop.

\section{Methods}

\section{Cells, reagents and viruses}

All cell cultures were maintained at $37^{\circ} \mathrm{C}$ in a $5 \% \mathrm{CO}_{2}$ humidified incubator. U937 (ATCC, \#CRL-1593.2), NB4 (M. Lanotte, INSERM UMR-S 1007, Paris, France) and R4, Huh7 and Huh7.5 (courtesy C. Richardson, Dalhousie University, Halifax, NS), Vero cells (ATCC, \#CCL-81) were maintained as described in [47]. Retinol and All-trans retinoic acid (ATRA) (Sigma-Aldrich Fine Chemicals, Oakville, ON) stock solutions of $10^{-2} \mathrm{M}$ were prepared in 100\% DMSO and further dilutions were performed using RPMI. DMSO at equivalent final dilutions was used in all experiments as a control. All retinoids were stored in opaque eppendorf tubes at $-80^{\circ} \mathrm{C}$. The Jones $\mathrm{MuV}$ strain (ATCC, \#VR-365) is a tissue culture-adapted virus that was, according to the supplier's web-site, extensively passaged in chicken embryos and Vero cells prior to purchase. Our MuV stock was initially plaque purified and then grown by infecting Vero cells with a maximum passage of three times from the original purchase (ATCC, \#CCL-81) at a multiplicity of infection (MOI) of 0.001 at $33^{\circ} \mathrm{C}$ in a Cell-Stack 10 (Corning, Corning, NY). Harvested virus was concentrated by centrifugation at $15,752 \mathrm{x} \mathrm{g}$ for seven hours at $4^{\circ} \mathrm{C}$ in a fix-angle rotor, the pellet was resuspended in RPMI with gentle pipetting. The Chicago-1 MeV strain is a tissue culture-adapted genotype D3 virus (courtesy of W. Bellini, CDC, Atlanta, GA). MeV stock was grown as described in [47].

\section{Cell culture infections}

Cell lines were infected with $\mathrm{MuV}$ at the indicated MOIs. Media was removed and virus diluted in Hanks' Balanced Salt Solution with calcium and magnesium (Wisent, St-Bruno, QC). The virus was incubated with the cells for 1.5 hours, with gentle rocking at 15-minute intervals. The virus was removed and cells were resuspended in RPMI 1640 supplemented as previously described [46-48] using the specific MOIs and time points indicated in the figure legends and incubated at $37^{\circ} \mathrm{C} / 5 \% \mathrm{CO}_{2}$.

\section{Quantitative RT-PCR}

RNA was extracted using Trizol (Invitrogen by Life Technologies, Burlington, $\mathrm{ON}$ ) as per the manufacturer's instructions, and treated to remove possible genomic DNA contamination with Turbo DNAse (Ambion, Austin, TX). For experiments in which antibodies were used to block type I IFN signalling, an RNeasy Mini kit was used to extract RNA (Qiagen, Mississauga, ON). Equal quantities of RNA 
were reverse-transcribed into cDNA for qPCR analysis using random primers. FAM-labelled TaqMan primer-probe assays for the following genes were obtained from ABI (Applied Biosystems by Life Technologies, Carlsbad CA): RIG-I, RAR $\beta$ and IRF-1. The level of gene expression in untreated cells was used for calibration. Vic-labeled hGAPDH was used as the endogenous control.

\section{Transwell}

Transwell experiments (TW) were performed as previously described $[47,48]$. Briefly, TW membranes inserts with 0.02 $\mu \mathrm{M}$ pores served to separate infected cells in the outer chamber from the uninfected bystander cells of the inner chamber. Wells with no transwell inserts were used for control cultures. Preliminary experiments demonstrated that the presence/absence of the TW membrane had no impact on measured outcomes under control conditions.

\section{Conditioned media}

Supernatants were collected from TWs and used to treat fresh U937 cells. After 24 hours of incubation with the TW conditioned media, RNA was extracted and RT PCR performed. These samples were analyzed by qPCR for the expression of RIG-I.

\section{Blocking antibody}

Supernatants were collected from TWs and used to treat fresh U937 cells. These fresh cells were treated with antiIFNAR2 blocking antibody $(20 \mu \mathrm{g} / \mu \mathrm{L}$, PBL Biomedical Laboratories, Piscataway, NJ) or isotype control antibody for one hour before infection and for the subsequent 24-hour incubation with the conditioned media. These samples were analyzed by qPCR for the expression of RIG-I.

\section{Western blotting}

Cells were infected with $\mathrm{MuV}$ and/or treated with ATRA at the indicated doses. 48 hours post infection, protein was harvested as previously described in [47]. The membranes were incubated in $5 \%$ non-fat milk or $5 \%$ BSA for 1 hour and incubated overnight at $4^{\circ} \mathrm{C}$ with primary antibody. Primary antibodies used were against phospho-STAT1 (Y701) (1/1000, BD Bioscience), Total STAT1 (1/1000, BD Bioscience) and $\beta$-actin (1/10000, Sigma). Following overnight incubation, membranes were washed three times for 10 minutes in TBS/0.1\% Tween, incubated with secondary antibody (1/10000, GE Healthcare) at room temperature for 30 minutes, and washed three times for 10 minutes. The peroxidaseconjugated secondary antibodies were developed using a chemiluminescence kit according to the manufacturer's instructions (GE Healthcare).

\section{Transfection}

Huh 7.5 cells were seeded at $1.5 \times 10^{5} \mathrm{cell} / \mathrm{mL}$, then were transfected with $3 \mu \mathrm{g}$ of the RIG-I construct in a pcDNA3 plasmid (gift from J. Hiscott) or empty vector using a 3:1 ratio of FuGENE 6 (Roche, Toronto, ON) as per the manufacturer's instructions. At 18 hours post-transfection, cells were infected with $\mathrm{MuV}$ MOI 0.01 and at 48 hours post infection the cells and supernatants were quantified using plaque assay as previously described [46].

\section{Viral challenge of bystander cells}

Bystander cells from the TW inner chambers were pooled according to treatment and resuspended in Hanks' Balanced Salt Solution with calcium and magnesium (Wisent, St-Bruno, QC). Cells are infected with $\mathrm{MuV}$ or $\mathrm{MeV}$ at MOI 0.1 as described above and previously [46-48]. These cells were resuspended in RPMI 1640 (Wisent, St-Bruno, QC) supplemented with 10\% heatinactivated FBS (Wisent, St-Bruno, QC) and $0.1 \%$ gentamicin and incubated for the indicated time at $37^{\circ} \mathrm{C} / 5 \% \mathrm{CO}_{2}$.

\section{Tissue culture infectious dose ${ }_{50}\left(\mathrm{TCID}_{50}\right)$}

$\mathrm{MuV}$ concentrations were quantified by $\mathrm{TCID}_{50}$. Briefly, Whole cells and supernatant were frozen at $-80^{\circ} \mathrm{C}$ to lyse cells, samples were defrosted on ice, then serially diluted in Minimum Essential Medium Eagle (Wisent, St-Bruno, QC) supplemented with 3\% heat-inactivated FBS (Wisent, St-Bruno, QC) and 0.1\% gentamicin. Supernatants were not analysed separately in this series of experiments. Diluted virus was applied to Vero cells in $3 \%$ heat-inactivated FBS (Wisent, St-Bruno, QC) and 0.1\% gentamicin in 96-well plates. The virus is incubated with the cells for 5 days at $37^{\circ} \mathrm{C} / 5 \% \mathrm{CO}_{2}$. Syncytium formation was scored and $\mathrm{TCID}_{50}$ was calculated using the Karber method [90,91].

\section{Elisa}

U937 cells were infected at an MOI of 0.01 with the indicated virus. At 48 hours post-infection, supernatant IFNa1 and IFN $\beta$ were measured by ELISA (PBL Interferon Source, Piscataway, NJ) as per the manufacturer's instructions.

\section{Competing interests}

The authors have no competing interest to declare.

\section{Authors' contributions}

KJS designed, completed, and analysed experiments, drafted and reviewed the manuscript; CT and LR designed and completed experiments; TZD and KHR drafted the model figure and revised the manuscript; WHM and BJW designed experiments and critically reviewed the manuscript. All authors read and approved the final manuscript.

\section{Acknowledgments}

We wish to thank Angela Brewer and Cynthia Guilbert for technical assistance, and to Dr. Koren Mann for feedback and support. Research funded by CIHR grant \#81254. KJS was funded by CIHR Doctoral Research Award (2009-2011). 


\section{Author details}

${ }^{1}$ Research Institute of the McGill University Health Center, Department of Infectious Diseases, McGill University, Montreal, Quebec, Canada. ${ }^{2}$ Segal Cancer Centre, Lady Davis Institute for Medical Research, SMBD Jewish General Hospital, McGill University, Montreal, Quebec, Canada. ${ }^{3}$ Montreal General Hospital, 1650 Cedar Ave., Room L10-309, Montreal, Quebec H3G $1 \mathrm{~A} 4$, Canada.

Received: 4 January 2013 Accepted: 30 October 2013

Published: 14 November 2013

\section{References}

1. Goodbourn S, Randall RE: The regulation of type i interferon production by paramyxoviruses. J Interferon Cytokine Res 2009, 29:539-548.

2. Hviid A, Rubin S, Muhlemann K: Mumps. Lancet 2008, 371:932-944.

3. WHO: WHO-recommended standards for surveillance of selected vaccine-preventable diseases. Geneva, Switzerland: Biologicals VAaMTotDoVa ed; 2003.

4. Carr MJ, Moss E, Waters A, Dean J, Jin L, Coughlan S, Connell J, Hall WW, Hassan J: Molecular epidemiological evaluation of the recent resurgence in mumps virus infections in Ireland. J Clin Microbiol 2010, 48:3288-3294.

5. Kuzmanovska G, Polozhani A, Mikik V, Stavridis K, Aleksoski B, Cvetanovska Z, Binnendijk R, Bosevska G: Mumps outbreak in the former Yugoslav republic of macedonia, january 2008-June 2009: epidemiology and control measures. Euro Surveill 2010, 15:1-9.

6. Whelan J, van Binnendijk R, Greenland K, Fanoy E, Khargi M, Yap K, Boot H, Veltman N, Swaan C, van der Bij A, et al: Ongoing mumps outbreak in a student population with high vaccination coverage, Netherlands, 2010. Euro Surveill 2010, 2010:15.

7. Bonebrake AL, Silkaitis C, Monga G, Galat A, Anderson J, Trad JT, Hedley K, Burgess N, Zembower TR: Effects of mumps outbreak in hospital, Chicago, Illinois, USA, 2006. Emerg Infect Dis 2010, 16:426-432.

8. CDC: Global measles mortality, 2000-2008. MMWR Morb Mortal Wkly Rep 2009, 58:1321-1326.

9. CDC: Update: mumps outbreak - New York and New Jersey, June 2009-January 2010. MMWR Morb Mortal Wkly Rep 2010, 59:125-129.

10. Stein-Zamir C, Shoob H, Abramson N, Tallen-Gozani E, Sokolov I, Zentner G: Mumps outbreak in Jerusalem affecting mainly male adolescents. Euro Surveill 2009, 14:1-3.

11. Bangor-Jones RD, Dowse GK, Giele CM, van Buynder PG, Hodge MM, Whitty MM: A prolonged mumps outbreak among highly vaccinated Aboriginal people in the Kimberley region of Western Australia. Med J Aust 2009, 191:398-401.

12. Roberts C, Porter-Jones G, Crocker J, Hart J: Mumps outbreak on the island of Anglesey, North Wales, December 2008-January, 2009. Euro Surveill 2009, 2009:14

13. Sommer A, Tarwotjo I, Djunaedi E, West KP Jr, Loeden AA, Tilden R, Mele L: Impact of vitamin A supplementation on childhood mortality: A randomised controlled community trial. Lancet 1986, 1:1169-1173.

14. Villamor E, Fawzi WW: Vitamin A supplementation: implications for morbidity and mortality in children. $J$ Infect Dis 2000, 182(Suppl 1):S122-S133.

15. Imdad A, Herzer K, Mayo-Wilson E, Yakoob MY, Bhutta ZA: Vitamin A supplementation for preventing morbidity and mortality in children from 6 months to 5 years of age. Cochrane Database Syst Rev 2010:1-27 (CD008524).

16. Barclay AJ, Foster A, Sommer A: Vitamin A supplements and mortality related to measles: a randomised clinical trial. Br Med J 1987. 294:294-296.

17. Huiming $Y$, Chaomin W, Meng M: Vitamin A for treating measles in children. Cochrane Database Syst Rev 2005:1-2 (CD001479).

18. Yang HM, Mao M, Wan C: Vitamin A for treating measles in children. Cochrane Database Syst Rev 2005:1-38 (CD001479).

19. D'Souza RM, D'Souza R: Vitamin A for the treatment of children with measles-a systematic review. J Trop Pediatr 2002, 48:323-327.

20. WHO/UNICEF: Joint WHO/UNICEF statement on vitamin A for measles. Int Nurs Rev 1988, 35:21.

21. Blomhoff R, Blomhoff HK: Overview of retinoid metabolism and function J Neurobiol 2006, 66:606-630.

22. Napoli JL: Retinoic acid: its biosynthesis and metabolism. Prog Nucleic Acid Res Mol Biol 1999, 63:139-188.

23. Mora JR, Iwata M, von Andrian UH: Vitamin effects on the immune system: vitamins A and D take centre stage. Nat Rev Immunol 2008 , 8:685-698.
24. Germain P, Chambon P, Eichele G, Evans RM, Lazar MA, Leid M, De Lera AR, Lotan R, Mangelsdorf DJ, Gronemeyer H: International union of pharmacology. LX. Retinoic acid receptors. Pharmacol Rev 2006, 58:712-725.

25. Clarke N, Jimenez-Lara AM, Voltz E, Gronemeyer H: Tumor suppressor IRF-1 mediates retinoid and interferon anticancer signaling to death ligand TRAIL. EMBO J 2004, 23:3051-3060.

26. Kolla V, Lindner DJ, Xiao W, Borden EC, Kalvakolanu DV: Modulation of interferon (IFN)-inducible gene expression by retinoic acid: Up-regulation of STAT1 protein in IFN-unresponsive cells. J Biol Chem 1996, 271:10508-10514.

27. Semba RD: Vitamin A, immunity, and infection. Clin Infect Dis 1994 19:489-499.

28. Creagh EM, O'Neill LA: TLRs, NLRs and RLRs: a trinity of pathogen sensors that co-operate in innate immunity. Trends Immunol 2006, 27:352-357.

29. van Boxel-Dezaire AH, Rani MR, Stark GR: Complex modulation of cell type-specific signaling in response to type I interferons. Immunity 2006, 25:361-372.

30. Percario ZA, Giandomenico V, Fiorucci G, Chiantore MV, Vannucchi S, Hiscott J, Affabris E, Romeo G: Retinoic acid is able to induce interferon regulatory factor 1 in squamous carcinoma cells via a STAT- 1 independent signalling pathway. Cell Growth Differ 1999, 10:263-270.

31. Pelicano L, Brumpt C, Pitha PM, Chelbi-Alix MK: Retinoic acid resistance in NB4 APL cells is associated with lack of interferon alpha synthesis Stat1 and p48 induction. Oncogene 1999, 18:3944-3953.

32. Pelicano L, Li F, Schindler C, Chelbi-Alix MK: Retinoic acid enhances the expression of interferon-induced proteins: evidence for multiple mechanisms of action. Oncogene 1997, 15:2349-2359.

33. Matikainen S, Ronni T, Hurme M, Pine R, Julkunen I: Retinoic acid activates interferon regulatory factor-1 gene expression in myeloid cells. Blood 1996, 88:114-123.

34. Luo XM, Ross AC: Physiological and receptor-selective retinoids modulate interferon $\gamma$ signaling by increasing the expression, nuclear localization, and functional activity of interferon regulatory factor-1. J Biol Chem 2005, 280:36228-36236

35. Luo XM, Ross AC: Retinoic acid exerts dual regulatory actions on the expression and nuclear localization of interferon regulatory factor-1. Exp Biol Med 2006, 231:619-631.

36. Liu TX, Zhang JW, Tao J, Zhang RB, Zhang QH, Zhao CJ, Tong JH, Lanotte M, Waxman S, Chen SJ, et al: Gene expression networks underlying retinoic acid-induced differentiation of acute promyelocytic leukemia cells. Blood 2000, 96:1496-1504.

37. Gianni M, Terao M, Fortino I, LiCalzi M, Viggiano V, Barbui T, Rambaldi A, Garattini E: Stat1 is induced and activated by all-trans retinoic acid in acute promyelocytic leukemia cells. Blood 1997, 89:1001-1012

38. Dimberg A, Nilsson K, Oberg F: Phosphorylation-deficient Stat1 inhibits retinoic acid-induced differentiation and cell cycle arrest in U-937 monoblasts. Blood 2000, 96:2870-2878.

39. Arany I, Whitehead WE, Grattendick KJ, Ember IA, Tyring SK: Suppression of growth by all-trans retinoic acid requires prolonged induction of interferon regulatory factor 1 in cervical squamous carcinoma ( $\mathrm{SiHa})$ cells. Clin Diagn Lab Immunol 2002, 9:1102-1106.

40. Plumet S, Herschke F, Bourhis J-M, Valentin H, Longhi S, Gerlier D: Cytosolic $5^{\prime}$-triphosphate ended viral leader transcript of measles virus as activator of the RIG I-mediated interferon response. PLOS ONE 2007, 2:e279.

41. Pichlmair A, Schulz O, Tan CP, Naslund TI, Liljestrom P, Weber F: Reis e Sousa C: RIG-I-mediated antiviral responses to single-stranded RNA bearing 5'-phosphates. Science 2006, 314:997-1001.

42. Hornung V, Ellegast J, Kim S, Brzozka K, Jung A, Kato H, Poeck H, Akira S, Conzelmann KK, Schlee M, et al: 5'-Triphosphate RNA is the ligand for RIG-I. Science 2006, 314:994-997.

43. Schmidt A, Schwerd T, Hamm W, Hellmuth JC, Cui S, Wenzel M, Hoffmann FS, Michallet MC, Besch $\mathrm{R}$, Hopfner KP, et al: 5'-triphosphate RNA requires base-paired structures to activate antiviral signaling via RIG-I. Proc Nat Acad Sci U S A 2009, 106:12067-12072.

44. Yoneyama M, Kikuchi M, Natsukawa T, Shinobu N, Imaizumi T, Miyagishi M, Taira K, Akira S, Fujita T: The RNA helicase RIG-I has an essential function in double-stranded RNA-induced innate antiviral responses. Nat Immunol 2004, 5:730-737.

45. Su ZZ, Sarkar D, Emdad L, Barral PM, Fisher PB: Central role of interferon regulatory factor-1 (IRF-1) in controlling retinoic acid inducible gene(RIG-I) expression. J Cell Physiol 2007, 213:502-510. 
46. Trottier C, Chabot S, Mann KK, Colombo M, Chatterjee A: Miller Jr WH, Ward BJ: Retinoids inhibit measles virus in vitro via nuclear retinoid receptor signaling pathways. Antiviral Res 2008, 80:45-53.

47. Soye KJ, Trottier C, Richardson CD, Ward BJ, Miller WH Jr: RIG-I Is Required for the Inhibition of Measles Virus by Retinoids. PloS one 2011, 6:e22323.

48. Trottier C, Colombo M, Mann KK, Miller WH Jr, Ward BJ: Retinoids inhibit measles virus through a type I IFN-dependent bystander effect. FASEB J 2009. fj.09-129288.

49. Harris P, Ralph P: Human leukemic models of myelomonocytic development: a review of the HL-60 and U937 cell lines. J Leukoc Biol 1985, 37:407-422.

50. Fujii N, Yokosawa N, Ishida S, Shirakawa S, Kubota T, Indoh T, Fujinaga K, Yashiki T: Investigation of IFN type-I receptor and IFN regulatory factor expression relating to induction of $2^{\prime}, 5^{\prime}$-oligoadenylate synthetase in cells persistently infected with the mumps virus. Microbiol Immunol 1996 40:777-781.

51. Indoh T, Shirakawa S, Kubota T, Yashiki T, Isogai E, Fujii N: Augmentation of interferon production after cell-differentiation of U937 cells by TPA. Microbiol Immunol 1996, 40:675-679.

52. Hariya $Y$, Yokosawa N, Yonekura N, Kohama G, Fuji N: Mumps virus can suppress the effective augmentation of HPC-induced apoptosis by IFN-gamma through disruption of IFN signaling in U937 cells Microbiol Immunol 2000, 44:537-541.

53. Pemrick SM, Lucas DA, Grippo JF: The retinoid receptors. Leukemia 1994, 8(Suppl 3):S1-S10.

54. Shao W, Benedetti L, Lamph WW, Nervi C, Miller WH Jr: A Retinoid-resistant acute promyelocytic leukemia subclone expresses a dominant negative PML-RARalpha mutation. Blood 1997, 89:4282-4289.

55. Zelent A, Guidez F, Melnick A, Waxman S, Licht JD: Translocations of the RARalpha gene in acute promyelocytic leukemia. Oncogene 2001, 20:7186-7203.

56. Blight KJ, Kolykhalov AA, Rice CM: Efficient Initiation of HCV RNA replication in cell culture. Science 2000, 290:1972-1974.

57. Blight KJ, McKeating JA, Rice CM: Highly permissive cell lines for subgenomic and genomic hepatitis C Virus RNA replication. J Virol 2002, 76:13001-13014.

58. Sumpter R Jr, Loo Y-M, Foy E, Li K, Yoneyama M, Fujita T, Lemon SM, Gale M $\mathrm{Jr}$ : Regulating intracellular antiviral defense and permissiveness to hepatitis C Virus RNA replication through a cellular RNA Helicase, RIG-I. J Virol 2005, 79:2689-2699.

59. Bridge AJ, Pebernard S, Ducraux A, Nicoulaz AL, Iggo R: Induction of an interferon response by RNAi vectors in mammalian cells. Nat Genet 2003, 34:263-264.

60. Kim DH, Longo M, Han Y, Lundberg $\mathrm{P}$, Cantin E, Rossi JJ: Interferon induction by siRNAs and ssRNAs synthesized by phage polymerase. Nat Biotechnol 2004, 22:321-325.

61. Kelly P: Nutrition, intestinal defence and the microbiome. Proc Nutr Soc 2010, 69:261-268.

62. Long KZ, Estrada-Garcia T, Rosado JL, Ignacio Santos J, Haas M, Firestone M, Bhagwat J, Young C, DuPont HL, Hertzmark E, Nanthakumar NN: The effect of vitamin A supplementation on the intestinal immune response in Mexican children is modified by pathogen infections and diarrhea. J Nutr 2006, 136:1365-1370.

63. Long KZ, Santos Jl, Rosado JL, Lopez-Saucedo C, Thompson-Bonilla R, Abonce M, DuPont HL, Hertzmark E, Estrada-Garcia T: Impact of vitamin A on selected gastrointestinal pathogen infections and associated diarrheal episodes among children in Mexico City, Mexico. J Infect Dis 2006, 194:1217-1225.

64. Long KZ, Garcia C, Santos Jl, Rosado JL, Hertzmark E, Dupont HL, Ko G: Vitamin A supplementation has divergent effects on norovirus infections and clinical symptoms among Mexican children. J Infect Dis 2007, 196:978-985.

65. Mehta S, Fawzi W: Effects of vitamins, including vitamin A, on HIV/AIDS patients. Vitam Horm 2007, 75:355-383.

66. Villamor E, Koulinska IN, Aboud S, Murrin C, Bosch RJ, Manji KP, Fawzi WW: Effect of vitamin supplements on HIV shedding in breast milk. Am J Clin Nutr 2010, 92:881-886.

67. Turpin JA, Vargo M, Meltzer MS: Enhanced HIV-1 replication in retinoid-treated monocytes: Retinoid effects mediated through mechanisms related to cell differentiation and to a direct transcriptional action on viral gene expression. J Immunol 1992, 148:2539-2546.
68. Maciaszek JW, Coniglio SJ, Talmage DA, Viglianti GA: Retinoid-induced repression of human immunodeficiency virus type 1 core promoter activity inhibits virus replication. J Virol 1998, 72:5862-5869.

69. Bocher WO, Wallasch C, Hohler T, Galle PR: All-trans retinoic acid for treatment of chronic hepatitis C. Liver Int 2008, 28:347-354.

70. Hamamoto S, Fukuda R, Ishimura N, Rumi MA, Kazumori H, Uchida Y, Kadowaki Y, Ishihara S, Kinoshita Y: 9-cis retinoic acid enhances the antiviral effect of interferon on hepatitis $C$ virus replication through increased expression of type I interferon receptor. J Lab Clin Med 2003, 141:58-66.

71. Siegel EM, Salemi JL, Craft NE, Villa LL, Ferenczy AS, Franco EL, Giuliano AR: No association between endogenous retinoic acid and human papillomavirus clearance or incident cervical lesions in Brazilian women. Cancer Prev Res 2010, 3:1007-1014.

72. Chen H, Zhuo Q, Yuan W, Wang J, Wu T: Vitamin A for preventing acute lower respiratory tract infections in children up to seven years of age. Cochrane Database Syst Rev 2008. CD006090.

73. Grotto I, Mimouni M, Gdalevich M, Mimouni D: Vitamin A supplementation and childhood morbidity from diarrhea and respiratory infections: a meta-analysis. J Pediatr 2003, 142:297-304.

74. Bresee JS, Fischer M, Dowell SF, Johnston BD, Biggs VM, Levine RS, Lingappa JR, Keyserling HL, Petersen KM, Bak JR, et al: Vitamin A therapy for children with respiratory syncytial virus infection: a multicenter trial in the United States. Pediatr Infect Dis J 1996, 15:777-782.

75. Sijtsma SR, Rombout JH, Dohmen MJ, West CE, van der Zijpp AJ: Effect of vitamin A deficiency on the activity of macrophages in Newcastle disease virus-infected chickens. Vet Immunol Immunopathol 1991, 28:17-27.

76. Sijtsma SR, West CE, Rombout JH, Van der Zijpp AJ: Effect of Newcastle disease virus infection on vitamin A metabolism in chickens. J Nutr 1989, 119:940-947.

77. Sijtsma SR, West CE, Rombout JH, Van der Zijpp AJ: The interaction between vitamin A status and Newcastle disease virus infection in chickens. J Nutr 1989, 119:932-939.

78. Rodeheffer $C$, von Messling V, Milot S, Lepine F, Manges AR, Ward BJ: Disease manifestations of canine distemper virus infection in ferrets are modulated by vitamin A status. J Nutr 2007, 137:1916-1922.

79. Blomhoff R, Green MH, Berg T, Norum KR: Transport and storage of vitamin A. Science 1990, 250:399-404

80. Rosas-Murrieta NH, Santos-López G, Reyes-Leyva J, Jurado FS, Herrera-Camacho I: Modulation of apoptosis by V protein mumps virus. Virol J 2011, 13:224.

81. Goodbourn S, Randall RE: The regulation of type I interferon production by paramyxoviruses. J Interferon Cytokine Res 2009 Sep, 29(9):539-547.

82. Ramachandran A, Horvath CM: Dissociation of paramyxovirus interferon evasion activities: universal and virus-specific requirements for conserved V protein amino acids in MDA5 interference. J Virol 2010 84:11152-11163.

83. Killip MJ, Young DF, Precious BL, Goodbourn S, Randall RE: Activation of the beta interferon promoter by paramyxoviruses in the absence of virus protein synthesis. J Gen Virol 2012, 93:299-307.

84. Childs K, Randall R, Goodbourn S: Paramyxovirus V proteins interact with the RNA Helicase LGP2 to inhibit RIG-I-dependent interferon induction. J Virol 2012 Apr, 86(7):3411-3421.

85. Stetson DB, Medzhitov R: Type I interferons in host defense. Immunity 2006, 25:373-381.

86. Weihua X, Kolla V, Kalvakolanu DV: Modulation of interferon action by Retinoids: induction of murine stat 1 gene expression by retinoic acid. J Biol Chem 1997, 272:9742-9748.

87. Chabot S, Ward BJ: Measles Virus (Rubeola). Philadelphia, PA: Lippincott, Williams and Wilkins; 2002.

88. Ni J, Wei J, Wu T: Vitamin A for non-measles pneumonia in children. Cochrane Database Syst Rev 2005:1-43 (CD003700)

89. Caselli E, Galvan M, Santoni F, Alvarez S, de Lera AR, Ivanova D, Gronemeyer H, Caruso A, Guidoboni M, Cassai E, et al: Retinoic acid analogues inhibit human herpesvirus 8 replication. Antivir Ther 2008, 13:199-209.

90. Kärber G: Beitrag zur kollektiven Behandlung pharmakologischer Reihenversuche. Naunyn Schmiedebergs Arch Pharmacol 1931, 162:480-483.

91. LaBarre DD, Lowy RJ: Improvements in methods for calculating virus titer estimates from TCID50 and plaque assays. J Virol Methods 2001, 96:107-126.

\section{doi:10.1186/1743-422X-10-337}

Cite this article as: Soye et al:: In vitro inhibition of mumps virus by retinoids. Virology Journal 2013 10:337. 